\title{
Em busca de novas estratégias de desenvolvimento
}

\author{
IGNACY SACHS
}

S NAÇões unidas convocaram para o mês de março de 1995, em
Copenhague, um encontro de cúpula dos chefes de Estado, consagrado
ao desenvolvimento social. A data da reunião está carregada de símbolos. É que 1995 marca o qüinquagésimo aniversário do lançamento da bomba atômica sobre Hiroshima, do fim da Segunda Guerra Mundial e da criação da ONU. Essa será, portanto, uma ocasião privilegiada para se estabelecer um balanço em claro-escuro do meio-século transcorrido, refletir sobre a possibilidade de se modificar o rumo dos próximos 50 anos e alcançar um resultado mais satisfatório em termos de paz e desenvolvimento, os dois objetivos centrais das Nações Unidas.

\section{O meio-século transcorrido}

Antes deveríamos dizer balanço em escuro-claro, porque, ao longo todo do período que se seguiu à Segunda Guerra Mundial, sucederam-se conflitos de cunho político, étnico e até mesmo religioso, violências institucionais, violações múltiplas dos direitos fundamentais, imposição de regimes autoritários e práticas de democracia de fachada.

Durante a Guerra Fria, o equilíbrio do terror entre as duas superpotências permitiu evitar o pior: o conflito mundial que levaria ao holocausto nuclear. $\mathrm{O}$ fim da Guerra Fria não conseguiu afastar por completo o perigo; reduziu-lhe, porém, consideravelmente, a probabilidade. Em contrapartida, conflitos locais têm-se multiplicado através do século, que se encerra com uma onda de genocídios na África e no coração da Europa, a qual vê assim ressurgir a longa seqüência de horrores: as duas guerras mundiais, os campos de extermínio e os gulag.

No entanto, no que diz respeito à geopolítica, duas mudanças maiores ocorreram: a descolonização e emancipação dos países colonizados ou dependentes (1), seguidas pelo desmoronamento do socialismo real em 1989 e, depois, o desmembramento da União Soviética. A isso convém acrescentar o fim do regime de apartheid na África do Sul, que se deu em 1994, e a esperança, que continua firme, de uma paz duradoura no Oriente Médio.

A descolonização tanto quanto o desmoronamento do socialismo real constituem duas rupturas históricas irreversíveis, cujas conseqüências continuam 
pesando, muito significativamente sobre o nosso presente. Para além das simplificações exageradas que pretendem substituir o esquema bipolar da Guerra Fria por um suposto choque de civilizações, a busca das identidades não deixa de representar um terreno fértil ao crescimento dos etnonacionalismos e fundamentalismos perigosamente anacrônicos. O historiador polonês Witold Kula (1960) definia o subdesenvolvimento como uma "coexistência de assincronismos". Nessa perspectiva, pode-se falar em involução ou processo de subdesenvolvimento bastante generalizado, simultâneo aos fenômenos de mundialização, cujos impactos econômicos e sociais diferenciados - positivos e negativos - exigem profunda avaliação. Uma apreciação uniformemente positiva de tais fenômenos remete antes à teologia do mercado do que a uma análise científica.

O período que acabamos de viver testemunhou um desenvolvimento sem precedente do poder tecnológico, do volume dos bens, dos serviços produzidos e das trocas comerciais. O estilo de consumo e o modo de viver transformaram-se profundamente para uma maioria de habitantes dos países industrializados e uma minoria dos países do Terceiro Mundo, sem que os progressos materiais indicados pela progressão das médias tivessem se generalizado. Num país tão rico como é a França, uma ruptura social separa hoje os dois terços dos ganhadores, do terço dos perdedores, cada vez mais excluídos da sociedade de consumo e privados do exercício de seu direito - que, porém, é fundamental - ao trabalho. Em outras palavras, a França, também, possui seu Quarto Mundo e o Sul está presente no Norte. A minoria privilegiada nos países do Terceiro Mundo constitui, em contrapartida, um Norte no Sul, sem que se possa falar de encraves territorialmente defendidos. O Norte e o Sul vivem lado a lado e se interpenetram, especialmente nas grandes cidades.

Com a revolução dos transportes e - em grau ainda mais significativo - a da comunicação, o mundo encolheu. Desses avanços tecnológicos é que se originam os fenômenos da mundialização já mencionados, os quais se manifestam de maneira desigual em campos tão variados quanto finanças, economia, tecnologia e cultura.

$\mathrm{Na}$ hora atual, estamos vivendo um "desacoplamento da economia financeira e da economia real” (Drucker, 1986) e, como conseqüência, a implantação de redes de especulação financeira que atraem capitais que poderiam ter financiado investimentos produtivos e contribuído para a criação de empregos. As empresas transnacionais assumiram o papel de protagonistas da economia e das trocas comerciais, a ponto de tornarem obsoletas as estatísticas da produção e do comércio internacional apresentadas na forma de agregados nacionais.

A midia espalha por toda a parte as mesmas representações da boa vida, baseada no consumo desenfreado e no sonho hollywoodiano. Reduzida minoria de homens e mulheres desloca-se com facilidade pelo mundo a ponto de transformar turismo e viagens em setor privilegiado da economia (3). A maioria dos 
habitantes de nosso planeta continua porém, vivendo como se fosse glebae adscripti. O contraste é marcante entre as restrições à mobilidade da mão-de-obra em escala internacional e a mobilidade cada vez maior dos demais fatores de produção.

O nosso domínio da ciência e da tecnologia continua bastante imperfeito. Prometeu estorvou a si mesmo, segundo uma metáfora de Jean Jacques Salomon (1984). O poder destruidor das tecnologias, cujo uso permanece subordinado à busca de projetos financeiros e econômicos de curto prazo, manifestou-se, por outro lado, pela degradação do meio-ambiente, cuja gestão prudente tornou-se um imperativo mundial, como o mostrou a conferência internacional Rio 92 sobre a Terra.

Acima de tudo, o progresso científico e técnico não cumpriu as promessas de um bem-estar generalizado para o conjunto da humanidade. Em 1930, Keynes pensava que o problema econômico da humanidade fosse definitivamente resolvido no espaço de um século. Pela primeira vez, desde seu aparecimento na Terra, o homem poderia então enfrentar seu problema verdadeiro: "Como empregar a liberdade arrancada aos entraves econômicos, como ocupar os tempos de lazer, que ciência e juros compostos haviam conquistado para ele, de modo agradável, prudente e bom?” (Keynes, 1971:136).

Nosso poder tecnológico seria, desde já, suficiente para oferecer a cada um dos homens um conforto material razoável. Segundo dados do Banco Mundial, a renda média per capita, em plano mundial, estava em 1992 na casa dos US\$ 4.300. Para efeito de comparação, a renda per capita no Reino Unido era de US\$ 4.593 em 1900 e a dos Estados Unidos, na mesma época, de US\$ 4.096 (Maddison, 1994).

Entretanto, a desigualdade que caracteriza a distribuição das rendas entre países e dentro dos países tira toda e qualquer significação de tal média. Em 1991, o quinto mais rico da população do mundo apropriava-se de $84,7 \%$ do PNB mundial, enquanto o quinto mais pobre estava reduzido a 1,4\%. Em 30 anos, a disparidade das rendas entre esses dois extremos passou de 30 por um a 60 por um.

Fato ainda mais importante nas sociedades modernas, a exclusão passou a liderar, superando a exploração. Os ricos já não precisam dos pobres. É provavelmente a razão por que tentam esquecê-los (5).

A distribuição cada vez mais desigual dos frutos dos progressos tecnológico e econômico resulta da má organização social e política, não da escassez de bens. Aponta para a responsabilidade do poder político, incapaz de assegurar o uso judicioso do poder tecnológico (Ruffolo, 1988). Estamos aqui no cerne da noção de maldesenvolvimento (Sachs, 1994), o qual não é incompatível com um crescimento da economia, até mesmo forte. É que crescimento e desenvolvimento 
não são sinônimos. Enquanto persistirem enormes disparidade sociais, o crescimento permanecerá, com certeza, uma condição necessária, embora de modo algum suficiente, do desenvolvimento, cujos aspectos distributivos e qualitativos não podem ser negligenciados. É um erro dizer que os exorbitantes custos sociais e ecológicos de certas formas de crescimento econômico constituem os danos inelutáveis do progresso.

Figura 1

O cálice da vergonha

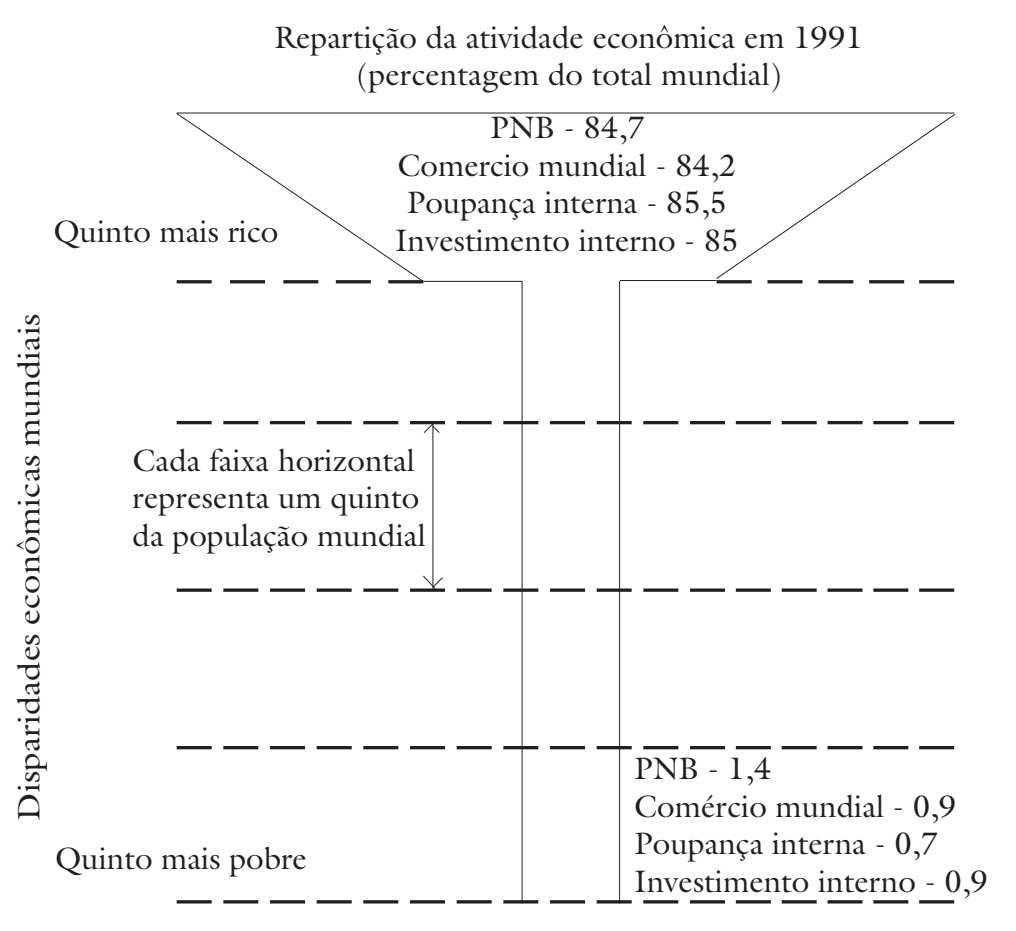

Fonte: PNUD - Relatório mundial sobre desenvolvimento humano, 1994:67.

\section{Progresso para quem?}

Essa problemática será abordada na Conferência sobre desenvolvimento social, que incluiu na sua ordem do dia os três pontos seguintes: luta contra a pobreza, integração social e criação de empregos produtivos. Não é aceitável nem necessário que os progressos financeiros e econômicos sejam pagos por desemprego ou subemprego estruturais, resultando em fenômenos cada vez mais generalizados de exclusão social e pobreza.

A articulação da ordem do dia de Copenhague, como foi, aliás, o caso da Rio-92, constitui uma recusa implícita de teorias economicistas que fazem do 
crescimento o objetivo central, se não o único. Assinala também o fim da crença na difusão quase automática dos resultados do crescimento econômico no conjunto da sociedade. Como escreve Louis Emmerij (1994), "ninguém poderia contestar o fato de que o crescimento econômico seja, a longo prazo, eficiente para alcançar os objetivos sociais e lutar contra a pobreza, mas de três a cinco gerações podem ser necessárias para chegar a essa meta. Em outros termos, o período de transição seria humanamente insuportável e politicamente irresponsável".

Eis a razão por que é necessário tratar simultaneamente os cinco temas: paz, economia, meio-ambiente, justiça e democracia tomando as condições sociais como ponto de partida dos esforços em prol do desenvolvimento (6). O presente texto tem um objetivo muito mais restrito. Limita-se a analisar os aspectos da problemática do desenvolvimento que parecem merecer atenção especial. A seguir, depois de examinarmos a crise generalizada no conjunto dos continentes, insistindo sobre a inserção produtiva por meio do emprego e auto-emprego, iniciaremos a busca de novos paradigmas de desenvolvimento, partindo dos seguintes temas: a superação do economicismo; a necessidade de uma axiologia universal; as relações entre o econômico, o ecológico e o social; a regulação democrática das economias; a redefinição do papel do Estado; as novas formas de parceria entre os atores sociais, a ciência e a tecnologia a serviço do desenvolvimento social; e as reformas do sistema internacional.

\section{A crise social generalizada}

A Conferência de Copenhague será confrontada com uma crise social generalizada, com formas e intensidades diferentes, que atinge, salvo poucas exceções, os países do Terceiro Mundo, os da Europa do Leste e da ex-União Soviética (chamados hoje países em transição) e até mesmo os países industrializados.

No Terceiro Mundo, aos antigos pobres, vítimas do subdesenvolvimento do aparelho produtivo, juntaram-se os novos pobres, vítimas de um conceito mimético de modernidade construído pela transposição das tecnologias mais modernas vindas dos países industrializados. É verdade que o uso seletivo dessas tecnologias se impõe. A abertura indiscriminada das economias do Sul, porém, seria capaz de intensificar os processos de dualismo da economia e da sociedade e, conseqüentemente, a aceleração das exclusões e a ameaça, em prazo indeterminado, do apartheid social.

Os países em transição devem enfrentar, simultaneamente, um desafio tríplice. Precisam estabilizar as economias; criar, a partir de nada, o conjunto das instituições necessárias ao funcionamento das economias, predominantemente a de mercado; enfim, reestruturar profundamente o aparelho de produção de modo a aumentar sua eficiência e competitividade nos mercados internacionais e seu desempenho no que diz respeito ao gerenciamento do meio-ambiente. Sob 
vários aspectos, os problemas dos países em transição se parecem com os dos países do Terceiro Mundo (7).

Transformação como essa não poderia, de qualquer forma, realizar-se sem custos sociais elevados. Porém, a escolha de uma nova estratégia inspirada pela ilusão de que fosse possível implantar imediatamente o capitalismo e o reino soberano da economia de mercado parece ter aumentado os custos e, até mesmo, prolongado sua duração além do necessário.

A degradação das relações sociais; a deterioração dos serviços de saúde, de educação e de previdência social; o aparecimento de desemprego estrutural importante e difícil de ser eliminado; a vulnerabilidade dos países em transição a um tratamento de choque representado pela abertura demasiadamente brusca de suas economias; a permissividade com relação às práticas do capitalismo selvagem constituem vários fatores que oneram negativamente o balanço da grande transformação, pelo menos até o presente momento.

Sem dúvida alguma, o elemento mais surpreendente da crise social é a deterioração da situação dos países industrializados, ocorrida após décadas de progressos econômico e tecnológico particularmente rápidos.

Quase se poderia dizer que estamos assistindo à sua terceiromundialização. É que a instrumentação intelectual criada antigamente para estudar a dualidade econômica e social dos países pós-coloniais e explicar os fenômenos de exclusão social e segregação espacial voltou à tona com intensidade no debate que agita atualmente a maior parte dos países industrializados. O desemprego, a crescente precariedade do trabalho e as diversas exclusões resultantes tornaram-se endêmicas. O eufemismo sociedade com ritmo dual não engana mais a ninguém. Marshall Wolfe (1994) distingue várias exclusões: as dos meios de subsistência livelihood, dos serviços sociais de proteção e redes de segurança, da cultura do consumo, do processo de escolhas políticas, das bases de organização popular e de solidariedade e, finalmente, da aptidão para compreender o que está acontecendo.

Tudo ocorre, portanto, ao oposto do que as teorias otimistas do desenvolvimento deixavam prever. No lugar do desaparecimento do setor tradicional pela transferência progressiva do excedente de sua mão-de-obra para o setor moderno, assistimos à expulsão das sobras de trabalhadores do setor moderno para setores de economia informal, de fundos de quintal ou nitidamente ilegal, até mesmo à sua marginalização pura e simples, fadados à aflição da ociosidade forçada, condenados à situação de assistidos, para alguns do berço ao túmulo.

No momento em que mais precisamos dele, o Estado-protetor (Welfare State) é levado ao banco dos réus e até parcialmente desmantelado sob o pretexto de custos excessivos, das complicações de sua burocracia e da suposta eficiência 
das fórmulas substitutivas que postulam a comercialização dos serviços sociais. Não há dúvida de que as modalidades de funcionamento dos Estados protetores devem mudar. Não se deve esquecer, porém, que constituem a única contribuição realmente positiva que a Europa tem dado ao mundo, neste século Xx, fruto de um século e meio de lutas sociais, assim como de competição com o socialismo real, na época em que ele tinha ainda credibilidade em importante parcela da opinião pública ocidental.

Mais do que nunca, os objetivos do pleno emprego e de proteção social generalizada e adequada representam um elemento fundamental da identidade européia. Em vez de defender a manutenção da legislação social na sua forma atual, é preciso inscrever na ordem do dia uma reforma profunda dos Estados protetores, sem para tanto desresponsabilizá-los e confiar unicamente nos mecanismos do mercado. A direção que deve ser tomada por essa reforma é clara: é preciso ajudar as sociedades a melhor se responsabilizarem por si mesmas com a ajuda do Estado, buscando formas múltiplas de parceria na produção de serviços sociais entre os usuários, a sociedade civil representada pelo mundo associativo e os outros componentes da economia social (cooperativas, sociedades de socorros mútuos), poderes públicos em todos os níveis, do local ao nacional e, enfim, as empresas (8).

Os três pontos da Conferência de Copenhague são estreitamente interligados. No entanto, parece-nos que a ordem lógica prioriza a implantação de políticas pró-ativas visando a cortar o mal pela raiz, por meio da inserção produtiva, do emprego ou do auto-emprego. As políticas assistenciais voltadas para os pobres são necessárias, sem dúvida, diante do tamanho e da urgência do problema da pobreza. Mas, por si sós, elas não trazem soluções duráveis. Os excluídos assistidos continuarão, enquanto não tiverem encontrado um lugar na economia.

Da mesma forma, a integração social que leva em conta numerosos fatores culturais e formas de organização social depende, em boa parte, da capacidade de assegurar ao conjunto dos diversos componentes da população, para além de suas diferenças sociais, étnicas e religiosas e de seu nível de educação, condições que lhes permitam, com o ganho de seu trabalho, alcançar uma vida decente.

A explosão demográfica é freqüentemente apresentada como a causa principal do subemprego e do desemprego agudos nos países do Sul. Essa tese, porém, necessita ser corrigida por uma leitura mais atenta da relação populaçãodesenvolvimento. Enquanto as populações do Sul não tiverem alcançado seguridade alimentar e social, enquanto conviverem com taxas de mortalidade infantil elevadas e sua educação, particularmente no que diz respeito às meninas, permanecer deficiente, ficará difícil persuadi-las da pertinência das políticas de controle da natalidade. A racionalidade fragmentada dessas políticas em nível familiar continuará chocando-se com a racionalidade global. A transição 
demográfica não pode dar certo se não houver desenvolvimento social baseado na inserção produtiva.

A prioridade que se deve dar ao problema do emprego e do auto-emprego é tanto maior quanto a ociosidade forçada (9) constitui uma forma irreversível de destruição das vidas humanas, já que o tempo perdido não pode ser nem detido nem recuperado. $\mathrm{O}$ verdadeiro desafio está em quebrar a dinâmica do desemprego e da exclusão, substituindo-a por uma dinâmica do emprego (Brunhes, 1993). A leitura das estatísticas e projeções demonstram a amplitude do problema.

O BIT elaborou projeções da população economicamente ativa (PEA) para o período 1995-2025, as quais nos servirão para avaliar a ordem de grandeza do número de empregos a ser criados, necessários para integrar os recém-chegados nos mercados de trabalho no decorrer da presente e das duas próximas décadas, isso sem levar em consideração a necessidade de reduzir gradativamente o desemprego existente (BIT, 1996).

De fato, como mostra o quadro 1 , de 1990 até o ano 2000, a população ativa, aumentaria de 389 milhões e, depois, no decorrer das duas primeiras décadas do século XXI, de 394 e 351,5 milhões respectivamente. Os novos empregos a serem criados localizar-se-iam essencialmente nas regiões menos desenvolvidas: $92,5 \%$ do aumento total entre 1990 e o ano $2000,97 \%$ entre 2000 e 2010 , mais de $100 \%$ entre 2010 e 2020 , uma vez que, no decorrer desse último período, a PEA das regiões mais desenvolvidas deverá conhecer uma redução de 400 milhões de pessoas.

Quadro 1

Crescimento da PEA (projeções do BIT)

\begin{tabular}{|lccc|}
\hline \multicolumn{1}{l}{ Regiões } & \multicolumn{2}{c|}{ em milhões } \\
\hline Menos desenvolvidas & 360 & 383 & 352 \\
Mais desenvolvidas & 29 & 11 & $-0,4$ \\
Mundo & 389 & 394 & 351,5 \\
\hline
\end{tabular}


Esses dados não levam em conta os desempregados e subempregados já existentes. Cerca de $30 \%$ da população ativa do mundo encontram-se nessa condição, segundo as estimativas das Nações Unidas. A absorção de tal contingente exigiria a criação de numerosos empregos adicionais. Segundo a Comissão Internacional pela Paz e Alimentação, para segurar o pleno emprego, seria preciso criar cerca de um bilhão de novos postos no decorrer da presente década (1994:71).

Conforme os dados do BIT, a situação das regiões mais desenvolvidas parece, à primeira vista, confortável, considerando que a taxa anual de crescimento da PEA é de apenas $0,49 \%$ no decorrer da presente década, passando para $0,34 \%$ na próxima. Criar aproximadamente três milhões de postos de trabalho por ano não deveria constituir problema, já que nos países de renda elevada a formação bruta do capital atingia em 1991, segundo dados do Banco Mundial, US\$ 3.750 bilhões (a serem comparados com US\$ 1.010 bilhões para o resto do mundo).

Na realidade, não é nada disso. Ao invés de criarem empregos, os investimentos produtivos tendem a substituir os homens por máquinas. Em numerosos setores industriais, a relação entre crescimento e emprego sofre uma inversão de sinal. A busca desenfreada da competitividade traduz-se por taxas de crescimento da produtividade superiores às taxas de crescimento da produção. Para citarmos apenas um exemplo, particularmente instrutivo, entre 1980 e 1992 a Espanha duplicou seu PIB sem criar um único emprego adicional. Encontramo-nos numa situação estruturalmente nova, que resulta da conjugação de vários fatores, dos quais mencionaremos quatro.

Os fatos desmentiram a expectativa otimista daqueles que, preconizando a corrida permanente para a inovação tecnológica (Riboud, 1987), prometiam um crescimento do emprego no setor dos serviços modernos superior ao número de empregos diretos suprimidos nas fábricas pela automatização. Os progressos recentes da informatização dos escritórios foram no mesmo sentido da substituição dos homens por máquinas no setor terciário.

Os laços entre produção e emprego se afrouxam. O crescimento intensivo predomina sobre o crescimento extensivo. Com relação à França, E. Malinvaud prevê, daqui a certo prazo, uma taxa de crescimento de 3\%, acompanhada por crescimento do emprego de $1 \%$ ao ano e diminuição do desemprego no ritmo anual de $0,5 \%(10)$.

Tal tendência, predominante na fase atual do progresso tecnológico, vai de par com a desconexão entre a economia real e a economia financeira, cujo desenvolvimento explosivo marca o fim do século xx (Drucker, 1986). Como já o dissemos, a atração pelos ganhos especulativos desvia para o grande cassino dos mercados financeiros os capitais, que poderiam ter sido investidos produtivamente e cuja esterilização reduz o crescimento da economia real. 
Dominadas pela ideologia do consumismo, as sociedades industriais não souberam aproveitar os ganhos da produtividade para realizar uma redução drástica do tempo de trabalho socialmente necessário.

É verdade que enquanto, no fim do século XIX o trabalho ocupava 200 mil horas na vida de um francês, atualmente ocupa apenas 70 mil horas (Rigaudiat, 1993). Mas agora existem as condições objetivas para acelerar essa evolução. De Kropotkine a Gorz e Illich, passando por Bertrand Russell e Keynes, muitos pensadores formularam propostas no sentido de uma revolução do tempo liberado e de uma reorganização da sociedade que permitisse menos trabalhar para todos trabalharem, retomando o título de uma obra recente (Aznar, 1993).

A crise atual parece favorecer a retomada do debate, cujas dimensões éticas e culturais vão muito além das modalidades técnicas de redução pontual do tempo de trabalho. A operacionalização de uma política de redistribuição eqüitativa do trabalho socialmente necessário exige verdadeira revolução cultural e transformações institucionais profundas (11). A situação pode, no entanto, ser melhorada pela modificação das políticas fiscais e parafiscais que aumentem o custo da mão-de-obra por meio de encargos sociais, os quais poderiam ser financiados de outra forma, por exemplo, por uma taxa sobre os equipamentos ou pela TVA devidamente modulada.

A evolução recente do pensamento econômico dominado pelas teorias neoliberais explica a insuficiência das políticas de emprego e, mais abrangentemente, das políticas públicas de desenvolvimento.

O declínio e, depois, o desmoronamento do socialismo real foram interpretados como um sinal verde para retornar a um capitalismo irrestrito, cujos sucessos se medem pela progressão dos índices de valores da Bolsa e pelo volume dos lucros, e não pela criação de empregos. Regras drásticas de ajuste dos equilíbrios macroeconômicos e monetários e de liberalização da economia foram decretadas pelo FMI e pelo Banco Mundial a fim de proteger os interesses dos credores dos países endividados. Embora o FMI e o Banco disso se defendam, as políticas de austeridade impuseram pesados sacrifícios às classes sociais mais desfavorecidas (12). Sob o pretexto de combater os excessos do estatismo, a desregulação, a privatização e a austeridade orçamentária foram utilizadas para reduzir o campo de ação dos Estados e reforçar a posição das grandes empresas nacionais e estrangeiras. Com poucas diferenças, a mesma estratégia foi proposta aos países em transição para a economia de mercado.

O fracasso dos países industrializados para reduzir o desemprego, apesar do potencial financeiro de que dispõem, permite medir a amplitude do desafio ao qual são confrontados os países menos desenvolvidos. No decorrer da presente década, teriam eles de criar 12 vezes mais postos, só para absorver os recém- 
chegados ao mercado de trabalho, isso com uma formação bruta de capital fixo quatro vezes inferior! Impõe-se imediatamente uma conclusão. É simplesmente impensável reproduzir-se nos países do Sul os modelos do Norte. Esses países tampouco podem submeter-se, em nome da competitividade, à inserção na economia global, ao ritmo infernal da destruição criadora, que os próprios países mais ricos têm dificuldade em manter.

Esse porém, é o caminho escolhido pelas elites do Terceiro Mundo. Entende-se a veemência com que Kothari as critica na obra já mencionada: ele propõe para a Índia uma abordagem do desenvolvimento baseada no reforço das capacidades da sociedade civil (social empowerment), na planificação descentralizada, antes na promoção dos empregos do que no crescimento enquanto tal, antes na prosperidade do campo e do mercado interno do que na prioridade excessiva dada às exportações.

Entre suas propostas, mencionaremos a ênfase na necessidade de considerar o emprego uma variável-chave das estratégias do desenvolvimento. Uma política adequada de emprego elaborada a partir dos dados locais aparece como elemento fundamental das políticas públicas de desenvolvimento, das quais tornaremos a falar posteriormente (13). Embora reconhecendo a gravidade da situação, acreditamos na existência de margens de manobra neste campo, mas com a condição de rever totalmente as metas e modalidades do desenvolvimento. Quando, no país das maravilhas, Alice pergunta polidamente para o gato como fazer para sair do lugar em que se encontrava, o gato lhe responde: "Depende em boa parte do lugar aonde você pretende ir".

\section{O desenvolvimento reavaliado}

O Relatório, já citado, da Comissão Internacional para a Paz e Alimentação (1994:154) considera, acertadamente, que a busca de novos paradigmas de desenvolvimento integra as grandes prioridades do momento. Se o estatismo leste-europeu desmoronou, nem por isso há lugar para o capitalismo irrestrito: "Ao invés de procurar um vencedor e um vencido, antes urge encontrar um sucessor que combine e sintetize os valores esclarecidos dos dois sistemas". O bem-estar de todos os homens é que deve determinar a política social e as economias de mercado devem se comprometer a garantir o direito de cada cidadão ao emprego.

O Relatório retoma e endossa a opinião do Secretário Geral da ONU, considerando a renovação do pensamento sobre desenvolvimento o mais importante desafio intelectual dos anos vindouros. O mundo possui experiências e informações suficientes para formular uma teoria integrada de desenvolvimento visto como processo social e cujo centro seja o homem e todos os homens. A Conferência Social Internacional de Copenhague deveria sinalizar o ponto de partida de tal processo. 
A tarefa é difícil. Supõe, por um lado, que se reconheça a existência de uma crise social generalizada que atinge, como já observamos, com modalidades e intensidades diferentes, todos os grupos de países, inclusive os industrializados.

\section{Superar o economicismo}

Por outro lado, exige a superação do economicismo, que ainda constitui a corrente dominante do pensamento e se traduz pela aceitação explícita ou implícita da teoria da percolação (trickle down theory), segundo a qual é a economia que está no comando. O essencial, portanto, consiste em garantir os controles macroeconômicos que permitam um crescimento razoável e o resto se fará por si mesmo. Os benefícios decorrentes de tal crescimento acabarão irrigando todo o tecido social, difundindo-se até a própria base da pirâmide. Se bem que a pauta da Conferência internacional sobre a Terra - Rio-92 - e, mais ainda, a da Conferência Social, desmintam implicitamente o trickle down, a prática de inúmeros governos continua apoiando essa teoria e as correntes neoliberais mais extremas a preconizam abertamente.

Outro elemento desse pensamento está em sobreestimar a importância da competitividade, alçada ao papel de verdadeira ideologia permeada por uma teoria superficial da mundialização apresentada unicamente em seus aspectos positivos, como se o aumento dos fluxos financeiros, comerciais e tecnológicos devesse sempre se realizar em benefício de todos os parceiros, inclusive dos mais fracos. O conceito de interdependência é muitas vezes utilizado para furtar-se do grau de assimetria, até mesmo de dominação existente na relação entre parceiros fortes e fracos. O Relatório do Grupo de Lisboa (1993) insurge-se contra a ideologia da competitividade, mostrando seus limites.

Quanto à mundialização, observaremos, em primeiro lugar, que sua progressão em diversos campos se dá de modo desigual. A unificação microbiana produziu-se antes do nascimento do mercado mundial, como mostram os historiadores.

Como já assinalamos, os mercados financeiros, que funcionam vinte e quatro horas por dia e sete dias por semana, movimentam uma massa de dinheiro totalmente desproporcional com relação às necessidades da economia real e a tentação dos ganhos fáceis, embora sujeitos a riscos, acaba esterilizando parte importante dos recursos que poderiam se ter traduzidos em investimentos produtivos. Avaliam-se em mil bilhões de dólares por dia as transações realizadas atualmente nos mercados monetários internacionais. A proposta judiciosa de James Tobin, formulada desde 1978, de taxar em até 0,5\% as operações de câmbio, renderia mais de mil e quinhentos bilhões de dólares por ano, que poderiam ser destinados para fins internacionais. Apesar de suas vantagens evidentes e do endosso pelo influente Relatório mundial sobre o desenvolvimento humano do PNUD (1944:75), tal proposta não tem muita chance de ser levada em consideração em Copenhague ou em qualquer outro lugar. 
A mundialização progride também a passos largos em matéria de comunicação. Os mesmos programas de televisão chegam aos quatro cantos do mundo com uma tendência à homogenização da cultura, que não deixa de levantar uma questão (Ortiza, 1994) e, o que é mais grave, abre caminho para a telecracia, termo inventado pelo jornal Le Monde no dia que se seguiu à vitória eleitoral de Silvio Berlusconi, na Itália.

O período de pós-guerra foi marcado por um avanço, com relação às permutas comerciais e tecnológicas, superior às taxas de crescimento econômico e, portanto, pela abertura das economias. Mais uma vez, a afirmação precisa ser temperada, na medida que o grau de abertura difere de um país para o outro. Em especial, os países de porte continental compensam por trocas internas o nível relativamente baixo das trocas externas. O peso dos Estados Unidos nas trocas mundiais não se prende a um grau elevado de abertura, mas no volume de seu PIB.

Certos ideólogos da mundialização, como Naisbitt (1995), esforçam-se por demonstrar que seus progressos conferem uma vantagem cada vez mais significativa às redes de pequenos parceiros, dotados da flexibilidade que os Estados $\mathrm{e}$ as grandes empresas não possuem. A argumentação de Naisbitt não deixa de ter uma parte de verdade quando fala de recuos identitários do Estado-nação para aquilo que chama as tribos. Segundo ele, um dos aspectos do paradoxo global é exatamente que "quanto mais universais nos tornamos, mais tribal se torna nosso modo de agir" (p.24). No decorrer da argumentação, o autor subestima o papel cada vez mais dominante na economia mundial das empresas transnacionais, que não param de aumentar o poder, enquanto a influência dos Estados se atenua e as instituições internacionais não têm praticamente qualquer domínio sobre as práticas dessas empresas.

O sentido amplo de seu livro consiste, porém, em exaltar, de modo insólito, o advento da idade do individualismo, o qual marca o fim da política tal como a conhecemos e, com isso, minimizar, e até mesmo desresponsabilizar o Estado com relação a suas funções sociais, particularmente em matéria de emprego. "Agora, com a revolução eletrônica, tanto a democracia representativa quanto as economias de escala tornaram-se obsoletas. Agora, cada um pode ter uma democracia eficiente direta" (p.47). As redes de comunicação é que se encarregarão disso. Ora, como salienta Dollfus (1994), o sistema que produz o espaçoMundo cria, ao mesmo tempo, formas de participação e de exclusão com relação aos processos de mundialização (15). Além disso, a mundialização baseia-se num projeto que desafia a riqueza das histórias, a pluralidade da humanidade. Por isso é que ela suscita, nos mais diversos lugares, seu contrário, isto é, o crescimento dos particularismos. Na realidade, como mostra de maneira profunda Badie (1994; Badie \& Smouts, 1992), estamos caminhando para uma nova desordem mundial motivada por uma ruptura tríplice marcada pela mundialização, pela crise do 
Estado-nação e pelo fim da bipolaridade. A natureza das oposições atuais já não é de ordem ideológica, mas cultural. O mundo atual caracteriza-se pelo fracasso de três conceitos-fetiches referentes às relações internacionais modernas: a soberania, a territorialidade e a segurança. $\mathrm{Na}$ medida que o nacionalismo se enfraquece em proveito dos microcomunitarismos e das solidariedades macrossociais (entre outras de tipo religioso), a ordem internacional entra em crise.

Outra característica do pensamento econômico dominante é que ele se considera universalmente válido, o que lhe confere na realidade um caráter a-histórico e utópico. Na prática, tal atitude nada mais é senão negar um campo próprio para as teorias do desenvolvimento e sustentar, contra tudo e contra todos, que a transposição mimética das experiências dos países industrializados para o resto do mundo constitui a via acertada que leva ao desenvolvimento. Os custos sociais proibitivos do ajuste estrutural aplicado de modo uniforme através do planeta acabaram de contrariar mais uma vez tal pretensão, sem que se observasse qualquer mudança nas práticas das organizações internacionais que se apóiam no consenso de Washington (16).

A pluralidade das vias de desenvolvimento está mais do que nunca na ordem do dia. As estratégias que levam a esse devem considerar certas especificidades comuns a vários países (por exemplo, países grandes e ricos em recursos naturais em oposição aos países pequenos e pobres dos mesmos recursos), o que permite conceber certas tipologias de tipo heurístico (17). É a mesma coisa no que diz respeito às singularidades próprias de cada país:

- o contexto histórico e cultural. O desenvolvimento deve ser apreendido em sua dinâmica processual (18);

- o contexto ecológico, a diversidade climática e biológica bem interpretadas traduzem-se por um potencial de recursos que podem ser aproveitados pelo desenvolvimento sem destruir em demasia o capital da natureza, já que o laço entre a diversidade natural e a cultural é bastante estreito; de fato, não se pode negar que uma face importante da própria cultura, para uma sociedade, diz respeito ao conhecimento que ela tem sobre seu meio natural (19).

- enfim, o contexto institucional, no sentido amplo do termo, que reflete a organização da sociedade humana.

$\mathrm{O}$ que se pode esperar da teoria do desenvolvimento diante da multiplicidade das trajetórias passadas, presentes e futuras, além de uma análise comparada das experiências acumuladas, positivas e negativas, que seja capaz de estimular a imaginação social sem por isso querer se livrar de modelos já prontos?

Pensamos que um discurso normativo é indispensável para precisar um projeto nacional mobilizador, baseado numa axiologia explícita, que reconhece o 
passado vivo mas está voltado para o futuro. Um projeto como esse tem, subsidiariamente, uma função muito importante enquanto critério de avaliação das políticas propostas e trajetórias cumpridas. As noções de racionalidade e eficiência tornam-se imprecisas na ausência de uma planificação estratégica orientada para o médio e longo prazos. Não se trata de reproduzir, mais uma vez, erros de planificação exaustiva praticada por economias de comando, mas, ao contrário, aproveitando todas as lições dos fracassos passados, engajar-se numa planificação flexível, dialógica (20), contextual e contratual.

\section{À procura de uma axiologia universal}

Num mundo em que, como já vimos, os particularismos culturais adquirem importância crescente, será possível construir a axiologia em torno de certos princípios universais?

Respondemos afirmativamente, à luz do debate inaugurado pela Conferência de Estocolmo em 1972 e retomado pela Conferência Internacional sobre a Terra - Rio-92. Pensamos que o desenvolvimento, no sentido forte da palavra, deve ter uma finalidade social justificada pelo postulado ético da solidariedade entre gerações e da eqüidade concretizada num contrato social. Numa época em que as disparidades, entre nações e no interior das nações, não cessaram de aumentar, é preciso fazer tudo para reduzi-las, o que supõe que os privilegiados se perguntem: "Quanto é o bastante?" (21). O desenvolvimento do homem todo e de todos os homens só poderá ser generalizado por meio da construção de uma civilização do ser, na partilha equilibrada do ter, segundo a fórmula lapidar de Lebret (22). A extrapolação das tendências atuais só pode, ao contrário, acentuar o desvio para o apartheid social.

Além disso, o desenvolvimento inclui a exigência de ser ecologicamente prudente em nome da solidariedade entre as gerações expressa num contrato natural (Serres, 1990).

Enfim, no plano instrumental, o princípio da eficiência econômica impõe-se: é preciso, porém, medi-lo pelo padrão macrossocial e não apenas pela lucratividade da empresa.

Subsidiariamente, podem ser mencionados dois outros princípios: a aceitabilidade cultural, sem que isso leve a renunciar à mudança em nome do respeito à tradição, e o equilíbrio territorial.

O desenvolvimento aparece assim como um conceito pluridimensional (24), evidenciado pelo uso abusivo de uma série de adjetivos que o acompanham: econômico, social, político, cultural, durável, viável e, finalmente, humano (25), e não citei todos. Está mais do que na hora de deixar de lado tais qualificativos 
para nos concentrarmos na definição do conteúdo da palavra desenvolvimento, partindo da hierarquização proposta: o social no comando, o ecológico enquanto restrição assumida e o econômico recolocado em seu papel instrumental.

Para além da semântica, há um problema muito mais temível para a prática. Trata-se da harmonização de objetivos que, à primeira vista, podem parecer contraditórios e, portanto, conduzirem a arbitragens dolorosas.

\section{O econômico e o ecológico}

Assim, o debate sobre desenvolvimento e meio-ambiente concentra-se essencialmente nas situações características de um jogo com resultado nulo. Não foram suficientemente exploradas, ao longo do caminho, as situações duplamente ganhadoras, as quais, no entanto, existem e poderiam ter sido multiplicadas, se os esforços de busca de uma solução tivessem ido nesse sentido. Podemos dar, como exemplo, os diversos casos de reciclagem, de agricultura chamada regenerativa e, sobretudo, das estratégias energéticas que permitem, ao mesmo tempo, reduzir consideravelmente o consumo das energias fósseis e poupar recursos financeiros (26). O nosso raciocínio aplica-se a outros recursos. Eis porque os fundadores do Clube Fator 10 têm razão de postular, para o próximo meio-século, a multiplicação por 10 da produtividade média dos recursos nas economias produtivas, enquanto precondição para que seja assegurado o desenvolvimento durável em escala mundial (27).

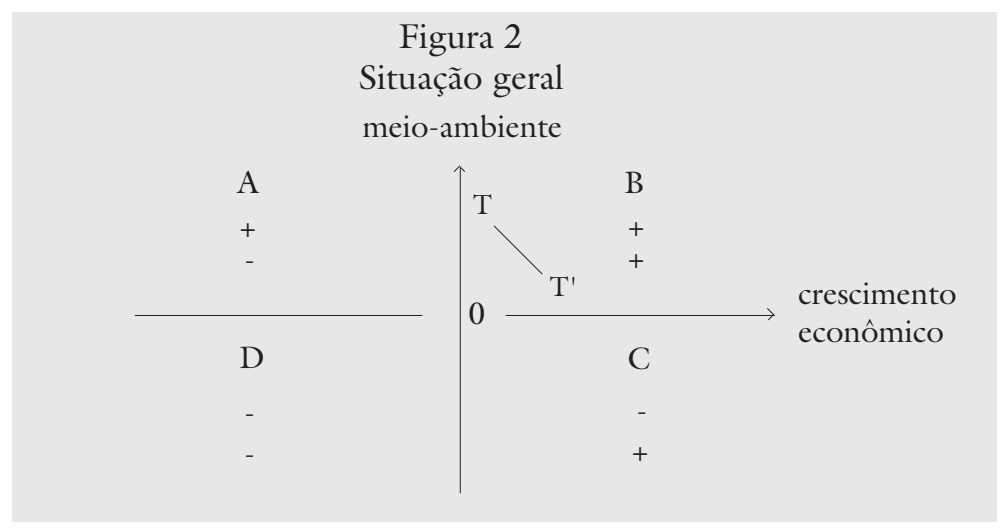

A situação geral está resumida na figura 2. O quadrante D simboliza o inferno. A e C correspondem a jogos com resultado nulo. No quadrante $\mathrm{A}$, a melhoria da situação do meio-ambiente implica em custos econômicos que levam à desaceleração do crescimento. O quadrante $\mathrm{B}$ é o do jogo com resultado positivo, em que se encontram os casos duplamente ganhadores. Em determinado momento, levando-se em conta os conhecimentos tecnológicos e organizacionais, o conjunto dos casos duplamente ganhadores pode ser representado por um traço TT'. O problema está em deslocar o traço TT' para a direita e para cima. 


\section{O econômico e o social}

A ordem do dia da Conferência de Copenhague introduz a relação entre o econômico e o social, enquanto a figura pressupunha tacitamente que o econômico e o social vão de par. Diante da importância que toma hoje o crescimento sem emprego e os fenômenos da exclusão que dele decorrem, a relação entre o econômico e o social é apresentada na figura 3.

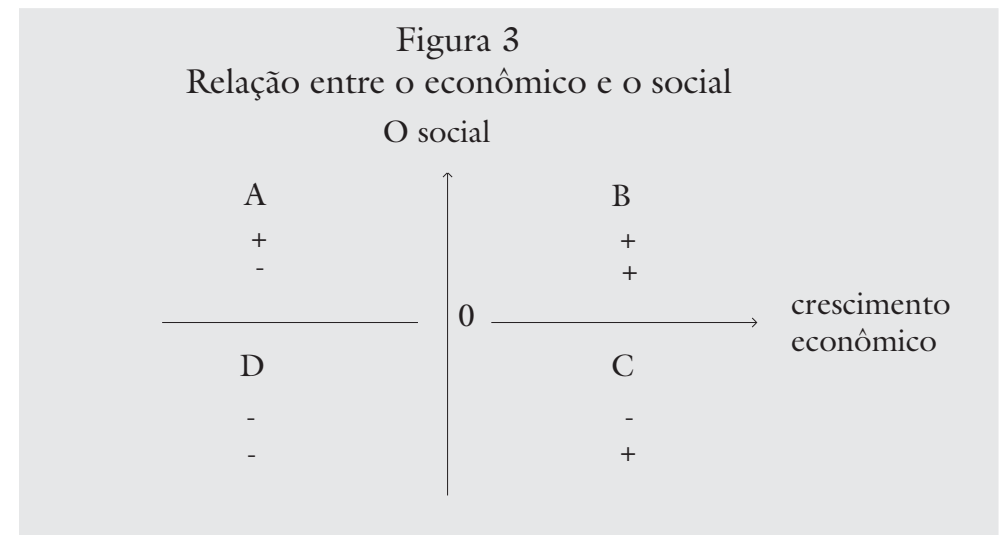

O quadrante $\mathrm{D}$, infelizmente muito presente na situação atual, é aquele em que a redução do crescimento leva à degradação social acentuada. O quadrante C corresponde ao crescimento que ocorre ao mesmo tempo que a redução do emprego e a degradação social decorrente de tal situação. O quadrante A representa as poucas situações em que a degradação econômica não destrói o tecido microssocial, que se caracteriza por grande coesão. O quadrante $\mathrm{B}$, mais uma vez, é o do jogo com resultado positivo, dentro do qual encontramos os casos duplamente ganhadores. Mas é preciso passar agora para os casos triplamente ganhadores, que permitem progressos nos três campos ao mesmo tempo: econômico, social e ecológico, e, portanto, realizam o desenvolvimento no sentido forte da palavra.

Propomos que o termo desenvolvimento seja reservado para esses casos, em oposição às diversas formas de maldesenvolvimento ou do desenvolvimento desequilibrado. O conjunto dos casos pertinentes está resumido no quadro 2.

Quadro 2

Tipo de Crescimento

\begin{tabular}{|lccc|}
\hline Crescimento & Econômico & Social & Ecológico \\
\hline selvagem & + & - & - \\
socialmente benigno & + & + & - \\
estável & + & - & + \\
desenvolvimento & + & + & + \\
\hline
\end{tabular}




\section{A regulação democrática das economias mistas}

Para alcançarmos situações triplamente ganhadoras, devemos repensar o quadro institucional no qual se concebe e se realiza o desenvolvimento. Uma vez afastados os dois extremos da economia, o de mercado em estado puro (uma utopia liberal no sentido forte desse termo) e o da economia de comando, a totalidade das situações reais existentes no mundo pertence à categoria de economias mistas, com múltiplos mercados de trabalho, bens e serviços, em que operam as empresas privadas com fins lucrativos, as empresas públicas e, de forma geral, os Estados, em todos os níveis, do central ao local, os diversos atores da economia social (cooperativas, sociedades de socorros mútuos, associações e organizações privadas com fins não-lucrativos) e o conjunto das populações que se dedicam parcialmente a atividades econômicas fora do mercado, realizadas no contexto doméstico (28). Para Tsuru (1993), a economia mista é, hoje, o único modo de produção que ainda existe. Saint-Geours (1992) dá mais um passo e considera a situação mista uma característica de nossas sociedades, para além do campo econômico.

Existe, é claro, uma multiplicidade de formas nesse quadro misto, que reúne público e privado. O que hoje chama a atenção é que a busca de novas formas de articulação entre os atores sociais diz respeito praticamente ao conjunto dos países do planeta, diante do vazio criado pelo desmoronamento do socialismo real, da crise que atinge os Estados protetores e o balanço aleatório do desenvolvimento, sobretudo do maldesenvolvimento no Sul.

O problema situa-se no plano daquilo que Streeten (1989) chama de mesoeconomia, e se prende particularmente ao fato de que as teorias sobreestimaram, por um lado, o papel dos controles macroeconômicos (evidentemente necessários, porém absolutamente insuficientes) e, por outro, o da atividade microeconômica dos empresários. Ora, há lugares em que a forma pela qual as coisas acontecem ainda hoje continua inversa ao esquema de Schumpeter: iniciativa e riscos são assumidos pelo Estado, de modo que a privatização a preços baixos beneficia uma categoria de empresários que nada têm de schumpeteriano. São três as questões centrais:

- que Estado, para que desenvolvimento?

- que conteúdo dar à democracia, para além do simples respeito às regras do jogo da democracia representativa no plano político?

- como chegar a novas formas de parceria entre o Estado, a sociedade civil e o mundo empresarial de modo que todo o potencial das iniciativas locais e ações da cidadania seja valorizado?

Examinaremos essas questões uma por uma. 


\section{Que Estado?}

Por várias razões, o debate atual sobre o Estado começou de forma errada. Ele se origina da oposição estabelecida entre Estado e mercado, enquanto, na realidade, todo mercado deve ser regulado pelo Estado, ainda mais se quisermos que a economia de mercado cumpra também uma função social. As críticas ao estatismo que, com razão, visam a seus excessos e ao peso da burocracia, simplificam exageradamente o problema ao postularem menos Estado, quando a verdadeira questão consiste em que ele, ao mesmo tempo, torne-se mais eficiente e menos oneroso. É de bom tom que se censurem as falhas do Estado, calando sobre as deficiências do mercado - às vezes tão numerosas quanto as do Estado -, sua incapacidade em apreender o longo prazo e o interesse social. De modo geral, é legítimo postular a redução do Estado empresário, sobretudo quando o setor público se compõe de empresas que foram nacionalizadas no momento em que estavam falidas e o Estado, ao intervir, privilegiou os interesses particulares de tal ou qual grupo próximo ao poder. Mas permanecem as funções do Estado-promotor (developmental State), a exemplo do que ocorreu no Japão, na Coréia do Sul, em Taiwan (29) e, sobretudo, do Estado-regulador. O desafio para os anos vindouros está em encontrar formas verdadeiramente democráticas de regulação das economias mistas.

O que nos leva à segunda questão.

\section{Apropriação de todos os direitos fundamentais}

O respeito aos direitos políticos, por si só, não é suficiente para definir democracia no sentido mais forte do termo. O exercício efetivo de todos os direitos políticos, cívicos, sociais, culturais e econômicos deve ser estendido ao conjunto da população, particularmente àqueles que, no presente momento, deles se acham excluídos. Tais direitos incluem o direito ao desenvolvimento individual e coletivo, assim como, é claro, o direito ao trabalho ou auto-emprego, assegurando assim uma vida decente e digna. Como já dissemos, só a inserção produtiva é que pode, de imediato, cortar pela raiz o mal da exclusão. As políticas assistenciais, por necessárias que sejam, em face da miséria dos desempregados e excluídos, não bastam: mesmo assistido, um excluído continua excluído. Embora não haja como renunciar às políticas de redistribuição de renda, é a repartição inscrita no modo de produção que deve, em primeiro lugar, merecer a nossa atenção.

Além das medidas referentes ao emprego, é urgente fornecer às populações carentes e marginalizadas instrumentos que lhes permitam melhor reivindicar seus direitos. Para alcançar tal objetivo é preciso promover a educação para a cidadania (30), isto é:

- conscientizar o conjunto das populações (crianças, jovens e adultos) e, 
particularmente, os grupos discriminados (mulheres, crianças quando for o caso, minorias culturais) sobre seus direitos e deveres.

- ensinar-lhes também como devem proceder em caso de não-respeito ou violação de seus direitos: como se organizarem? Aonde buscar apoios eficientes? Para quem apelar no plano prático e moral? Como mobilizar a opinião pública?

Paralelamente, para garantir uma participação real no dia a dia das populações nos processos de decisão e gestão, há necessidade de serem analisados de maneira aprofundada os contextos institucionais e as relações entre os atores envolvidos - a sociedade civil organizada (associações que lutam pela cidadania e movimentos sociais), a economia social, as autoridades públicas em todos os níveis e o mundo das empresas. De forma mais especial é preciso debruçar-se sobre:

- as instituições mediadoras entre as populações e o Estado, que vão além da simples democracia representativa (ombudsman, fóruns e conselhos consultivos, advocacy planning, formas de cooperação institucionalizada entre poderes públicos e associações em prol da cidadania. interativa).

- as práticas da democracia direta (referendos, pesquisas de opinião, mídia

- as políticas de discriminação positiva (e seus efeitos freqüentemente perversos).

\section{Novas formas de parceria entre os atores sociais}

No plano retórico, a participação ocupa bastante espaço no discurso sobre desenvolvimento. A realidade manifesta muitas vezes a imposição de estratégias elaboradas no escalão central. A reabilitação da abordagem inversa, que privilegia as iniciativas vindas da base, deve ser providenciada, especialmente no que diz respeito à identificação das necessidades reais da população e à hierarquia das urgências (31). Para tanto, deverá ser fortalecida a capacidade das populações para responsabilizarem-se por boa parte das decisões que lhes dizem respeito (conceito expresso pelo termo inglês empowerment .

Dois obstáculos, porém, devem ser evitados.

Em primeiro lugar, existem ambigüidades sabiamente manipuladas em torno desse conceito. Fiedmann (1992) fez dele, com toda razão, a pedra angular da busca de estratégias alternativas de desenvolvimento. Não convém, porém, esquecer que a mesma palavra era freqüentemente usada pelo presidente Reagan e, na expressão dele, significava que o Estado devia se livrar de algumas de suas responsabilidades sobre os poderes locais. Uma interpretação diluída do conceito encontra-se na base do programa comunitário preconizado por Etzioni (1993). 
O mesmo tipo de ambigüidade paira sobre o conceito de subsidiariedade caro à Comissão Européia. Uma decisão que pode ser tomada no escalão inferior não deveria ser levada ao superior. Mas quem decide se vai ser levada ou não?

Em segundo lugar, seria ilusório esperar que a complexidade do mundo atual permitisse se satisfazer com a simples justaposição de estratégias locais. A articulação dos espaços de desenvolvimento do nível local aos níveis regional, nacional e transnacional constitui um campo privilegiado da política. O desequilíbrio atual, que favorece o escalão central, assim como a incapacidade desse para conceber estratégias finamente adaptadas aos contextos locais exigem que sejam encorajadas as iniciativas da base. Elas, porém, terão de ser compatibilizadas e assistidas por complementação exterior dos recursos criticamente necessários que não podem ser mobilizados localmente.

Em outras palavras, cabe harmonizar as políticas públicas e as ações ligadas à prática da cidadania. Esse tema, importante para a Conferência Social Internacional foi debatido na conferência organizada em dezembro de 1994, pela Unesco, em colaboração com a cidade e a Universidade de Bolonha. A conferência examinou vários exemplos concretos da articulação entre os movimentos ligados à prática da cidadania e as políticas do Estado, principalmente o programa da luta contra a fome e pela cidadania no Brasil (32), o programa solidariedade no México, o papel das organizações em prol da cidadania na luta contra a exclusão na Polônia. Além disso, discutiu as perspectivas do fim do apartheid na África do Sul, os estudos realizados na Europa sobre a reforma dos Estados-protetores, até mesmo a implantação de uma sociedade que se responsabilize melhor por si própria (caring society) (33), por meio da parceria entre os interessados. O desenvolvimento dos serviços sociais, educacionais, ligados à saúde, mas também daqueles referentes ao aproveitamento lúdico do tempo liberado do trabalho, oferece um amplo campo para novas formas de parceria entre usuários, mundo associativo, poderes locais e empresas.

Esse campo de atuação é especialmente interessante para os países do Sul ou do Leste, onde, no momento, está baixo o nível dos salários. De fato, como a produtividade dos professores primários, dos enfermeiros ou das assistentes sociais é aproximadamente a mesma em todos os países do mundo, a produção de tal serviço nos referidos países é barata em termos absolutos em comparação com aquilo que representam os custos nos países em que o nível médio dos salários é bem mais alto. Com pequena modificação no volume de recursos atribuídos aos serviços sociais, no sentido amplo da palavra, seria então possível obter melhoria sensível da qualidade de vida nos países pobres. Em vez de esperar a prosperidade para começar a desenvolver os serviços sociais, convém, ao contrário esforçar-se sem demora por fazê-lo imediatamente. 
A mesa-redonda final de Bolonha foi consagrada às experiências urbanas na Itália. Mostrou a riqueza, a variedade e a importância das experimentações concretas realizadas por municipalidades. As cidades, cuja diversidade quase infinita foi muito bem salientada por Ítalo Calvino (1974), são de fato o cadinho em que nascem e se pensam as formas novas da cidadania, e a Itália, há séculos, funciona nesse setor como um prodigioso laboratório. Precisa haver um despertar da cidadania urbana, se quisermos de verdade que nossas cidades do século XXI se tornem lugares habitáveis. Uma ambição como essa não oneraria as nossas economias, especialmente em se tratando dos países industrializados, mais do que o fizeram as catedrais na Idade Média. A crise urbana exige tratamento prioritário. Igualmente, no contexto urbano apresenta-se de forma mais aguda a questão das relações interétnicas, interculturais e inter-religiosas, fonte de inúmeros conflitos e violência endêmica sobretudo nas situações em que a mescla social e cultural se sobrepõe aos fenômenos de exclusão social (34).

\section{A ciência e a tecnologia \\ a serviço do desenvolvimento social}

A técnica constitui uma variável-chave para a harmonização das políticas sociais, econômicas e ambientais. Será que se pode pensar em frear a tendência poderosa do progresso tecnológico atual de se traduzir pelo crescimento sem emprego? Qual é o papel que poderia cumprir, nesse campo, a reorientação da pesquisa científica?

A pergunta foi feita a pesquisadores reunidos no colóquio internacional, realizado em dezembro de 1994, em Nova-Delhi, organizado pela Unesco e pelo National Institute for Science, Technology and Development Studies. Foi-lhes perguntado, particularmente, quais eram as contribuições potenciais das ciências e tecnologias com relação aos três pontos de uma estratégia potencial de desenvolvimento orientado para a exploração de três fontes de empregos, como sucintamente descritos:

- o funcionamento das economias caracteriza-se atualmente por desperdício, mais ou menos acentuado, conforme os casos, de energia, da água e de outros recursos naturais. Progressos consideráveis ficam por fazer em matéria de reciclagem dos dejetos industriais e materiais. Além disso, manutenção mais metódica dos equipamentos, da área construída e das infra-estruturas, traduzindo-se pela prorrogação de sua vida útil, é uma das maneiras de economizar capital. Tais atividades, fortemente criadoras de empregos, autofinanciam-se, pelo menos parcialmente, pela poupança dos recursos físicos e do capital por elas trazido;

- no setor rural, a batalha decisiva pelo emprego dar-se-á em torno do futuro da pequena propriedade agrícola. É verdade que ela está predestinada a desaparecer em algum tempo, na hipótese da extrapolação das tendências poderosas 
atualmente observadas em matéria de progresso técnico na agricultura. Mas com condição de ser bem gerenciada, a nova fase da revolução verde permite encarar a modernização da agricultura em benefício do pequeno agricultor. Convém acrescentar que a melhor utilização das áreas agrícolas disponíveis interessa também aos países industrializados, à medida em que desejam evitar que essas áreas se transformem de arquipélago urbano em deserto rural.

Por outro lado, há também a necessidade de empenho na geração de empregos rurais não-agrícolas, o que pode ser conseguido de dois modos:

- mediante o desenvolvimento das agroindústrias transformadoras da biomassa e a substituição das energias fósseis pelas bioenergias; graças à descentralização das indústrias e de atividades terciárias, que se tornaram possíveis pelos progressos da telecomunicação e pela importância dada hoje à especialização flexível;

- em ultimo lugar, cabe mencionar o dossiê clássico das obras públicas, setor no qual as escolhas técnicas não são ditadas pela concorrência internacional. As necessidades em infra-estrutura são particularmente urgentes nos países em que a competitividade sistêmica muito deixa a desejar. Enquanto ela não tiver sido melhorada, os investimentos pontuais para aumentar a produtividade nas empresas serão em grande parte perdidos.

Os debates de Delhi concentraram-se especialmente nos dois primeiros pontos. Os trabalhos apresentados pelos participantes permitiram verificar a importância que os dois países mais povoados do mundo - a Índia e a China dão à preparação das estratégias de desenvolvimento fortemente geradoras de empregos rurais, agrícolas e industriais e que, por outro lado, caracterizam-se pela preservação dos recursos raros tais como solos agrícolas e água. Em ambos os casos, trata-se, na medida do possível, de reduzir as migrações cidades-campo. Uma hiperurbanização, conforme o modelo da América Latina, resultaria em desastres econômico, social e ecológico.

Numerosos trabalhos indianos, assim como as experimentações de campo conduzidas por grupo ASTRA, do Indian Institute of Science em Bangalore; Fundação Swaminathan, em Madras; e grupo Development Alternatives, em Delhi, para citar apenas alguns, mostram ser possível utilizar as biotecnologias nas menores fazendas de tipo familiar (35), idealizar, nos próprios vilarejos, sistemas integrados de produção de alimentos e energia tirados da biomassa (36) e criar empregos industriais no campo, com investimentos bastante reduzidos e produtividade razoável. As experiências pioneiras - que ainda são poucas - realizadas por Development Alternatives mencionam a criação de empregos estáveis em pequenas empresas, construção de barragens e no gerenciamento dos solos e das águas, que, em determinados casos, exigem apenas de US\$ 200 a 300 por emprego criado. 
O programa chinês de difusão da ciência e das técnicas modernas em meio rural, chamado Faísca, já contribuiu, segundo comunicou seu representante, à criação de centenas de milhões de empregos rurais não-agrícolas. Ashok Jain, diretor do NISTADS, apresentou uma análise muito aprimorada das perspectivas da industrialização descentralizada na Índia, que leva em consideração as experiências da terza Italia (37).

A importância da reunião de Delhi prende-se ao fato de ter revelado a existência de uma corrente de pensamento e ação que se entrechoca com as tendências poderosas dominantes, o que permite encarar com certa serenidade os desafios extremamente complicados que os países do Sul densamente povoados devem enfrentar. Essa mensagem aparece claramente na importante obra coletiva sobre a ciência, a população e o desenvolvimento organizada por Gowariker (1992) com o sugestivo título O inevitável bilhão e mais. As condições para obter sucesso estão em não sujeitar a pesquisa nos países do Sul aos modos dominantes nos laboratórios do Norte e não aguardar passivamente a transferência das tecnologias idealizadas sob outras latitudes e em outros contextos. A ambição de superar os países industrializados em determinados pontos de pesquisa é absolutamente legítima. O fortalecimento da capacidade local em matéria de ciência, tecnologia e formação de executivos altamente qualificados constitui ponto fundamental das estratégias de desenvolvimento baseadas na aptidão de elementos nativos para pensarem de maneira autônoma e por em execução os projetos nacionais.

Os autores do já citado relatório da Comissão Internacional pela Paz e Alimentação consideraram viável uma estratégia que assegurasse a criação de um bilhão de novos empregos nos países do Sul em apenas dez anos (p. 198-199). Tal proposta generaliza os resultados de um estudo, no qual o objetivo fixado era o de alcançar, em apenas uma década, o pleno emprego na Índia, o que elevaria o conjunto da população indiana acima do limite de pobreza (p. 122124). Para tanto precisaria criar 100 milhões de novos empregos, entre os quais 45 milhões na agricultura, 10 milhões nas agroindústrias rurais e 45 milhões de empregos rurais e urbanos devido ao efeito multiplicador do aumento do consumo das massas rurais, já que a agricultura constitui, ao mesmo tempo, uma fonte de alimentos e biomassa, e um mercado para produtos industriais e serviços. Segundo os autores dessa estratégia incorporada no VIII Plano Indiano, a Índia poderia alcançar tal resultado espetacular sem o aporte de recursos externos além dos investimentos diretos das empresas agroindustriais. Com a condição, porém, de que o país pudesse exportar os próprios excedentes agrícolas sem que lhe fosse impedido o acesso aos mercados dos países industrializados. O relatório, portanto, ataca fortemente o protecionismo agrícola dos países desenvolvidos e sugere a estratégia mundial de desenvolvimento do Sul, mediante a expansão de suas exportações de origem agrícola ou florestal. 
Atualmente, $58 \%$ da população economicamente ativa nos países do Sul, isto é, l bilhão e 100 milhões de homens, mulheres e crianças trabalham na agricultura, enquanto são apenas 35 milhões nos países industrializados. Tal raciocínio baseia-se inteiramente em uma avaliação controvertida do potencial da agricultura no que diz respeito ao futuro. Segundo os autores do relatório, as reservas disponíveis de solos e água para a agricultura poderiam facilmente duplicar em escala planetária e a produtividade por hectare aumentar de forma considerável.

O que, antes de tudo, merece nossa atenção nessa proposta surpreendentemente otimista é a idéia de, ao contrário do que afirma um preconceito bastante difundido, a agricultura poder assumir papel motor no desenvolvimento, pelo menos em certos países da Ásia, África e América Latina, com a condição de concentrarem-se em culturas que necessitam de numerosa mão-de-obra e de praticar manejo cuidadoso dos solos, dos micronutrientes e da água, com a ajuda de tecnologias intensivas ligadas a conhecimentos científicos.

Um complemento a tal estratégia consiste em explorar a biodiversidade e a diversidade cultural para encontrar novos recursos e gerenciá-los de forma socialmente útil e ecologicamente prudente, de modo que seja aumentada, em base duradoura, a capacidade dos ecossistemas, pressupondo que se recorra simultaneamente aos conhecimentos acumulados pelas populações, assim como às conquistas da ciência moderna (38).

\section{Que reformas do sistema internacional?}

Ficaria incompleta nossa análise se não mencionássemos a necessidade de reavaliar o funcionamento do sistema onusiano e das instituições de Bretton Woods (39), para criar condições internacionais mais favoráveis ao desenvolvimento, lembrando especialmente que a eqüidade nas relações internacionais supõe modificações das regras do jogo em benefício dos parceiros mais fracos, princípio que foi respeitado no momento da criação da CNUOED. será que o mesmo acontecerá no que concerne à futura Organização Mundial do Comércio?

De que modo agir para que seja atribuído aos movimentos sociais e às associações ligadas ao exercício da cidadania um papel mais ativo, e não apenas o lugar insignificante ocupado por eles, atualmente, no funcionamento das grandes organizações internacionais? No contexto da Conferência de Copenhague, convém examinarmos dois aspectos dessa última questão. Por um lado, o setor associativo poderia encarregar-se da preparação dos relatórios de cidadania sobre as condições sociais do mundo, a exemplo do que foi feito na Índia para o meio-ambiente. Por outro lado, impõe-se uma reflexão sobre a criação de um foro especial que desfrute de autoridade incontestável, não represente os governos, para os quais as organizações ligadas ao exercício da cidadania poderiam recorrer e cujo papel 
consistiria, antes de tudo, em alertar a opinião pública sobre as violações do conjunto dos direitos políticos, cívicos, sociais, culturais e econômicos, assim como em influenciar o funcionamento das instâncias governamentais e intergovernamentais.

\section{À guisa de conclusão}

Por sua vocação, seu passado e seu potencial, a UNESCO é chamada a cumprir o papel principal na coordenação da busca e operacionalização de novos paradigmas e políticas de desenvolvimento. Iniciativa suscetível de contribuir para tal objetivo foi a criação, em 1994, dentro da Organização, do programa MOST.

Entre os temas que acabamos de evocar, alguns já suscitaram grupos de trabalho, hoje em plena atividade, especialmente no que diz respeito à educação e à cultura, áreas em que trabalham atualmente duas comissões internacionais criadas pela UNESCO (40). Outras precisam ser estabelecidas em colaboração com outras organizações internacionais, com instituições governamentais e comunidades de pesquisadores. A tarefa mais imediata consistirá em organizar um acompanhamento detalhado da realização das recomendações da Conferência Social Internacional, num diálogo permanente com as associações de cidadania, e elaborar, em perspectiva plurianual, um programa de atividades correspondente às prioridades que serão estabelecidas em Copenhague.

Notas

1 As principais datas a ser lembradas são: 1947, a independência da Índia; - 1949, a vitória da Revolução chinesa; - 1955, a conferência de solidariedade dos países da Ásia e da África, em Bandung; - 1960, a descolonização da África.

2 A atenção quase exclusiva dada aos progressos do setor audiovisual relega a segundo plano a segunda revolução de Gutenberg, que está ocorrendo neste momento e abre possibilidades extraordinárias para produção de livros e manuais escolares. Estamos nos referindo à diminuição, bastante sensível, dos custos de produção de obras que se beneficiam de grandes tiragens. Às coleções italianas de livros com 100 páginas, por 100 liras, sucederam-se coleções inglesas e francesas de grandes clássicos, com várias centenas de páginas, vendidas respectivamente por uma libra esterlina e dez francos.

3 Segundo Naisbitt (1995:132-133), turismo e viagens empregam no mundo 204 milhões de pessoas e correspondem a 10,2\% do PNB mundial, e a eles se destinam cerca de $11 \%$ das despesas dos consumidores. De maneira bastante otimista, Naisbitt avalia em 144 milhões os novos empregos a serem criados nos diversos setores até o ano 2005. Cerca da metade corresponde à região Ásia-Pacífico.

4 Ver também, do mesmo autor, Le destin technologique (1992) e o ensaio de Giorgio Ruffolo (1988). 
5 É aquilo que denuncia com vigor Rajni Kothari (1993). Por sua vez, Jacques Delors afirma: "Já estamos vivendo, infelizmente, numa sociedade que se comove diante das injustiças, participa, volta e meia, de uma jornada-caridade televisionada, dá dinheiro e, fora disso, vive com a consciência tranqüila. É uma situação horrorosa, mas é o que nos ameaça cada vez mais." Entrevista ao jornal Le Monde, em 15 de novembro de 1994. Ver também Marshall Wolf (1994:1), para quem a própria palavra exclusão indica o caráter supérfluo dos excluídos em oposição à incorporação na economia em condições de exploração, assim como a ausência de qualquer poder. Uma obra fundamental consagrada à desagregação da sociedade e às metamorfoses da questão social, publicada recentemente. Robert Castel (1995:22) prefere falar em "invalidação social".

6 Ver a esse respeito o relatório do Secretário Geral das Nações Unidas, intitulado Desenvolvimento e cooperação econômica internacional - Agenda para o desenvolvimento, documento A-48-935 de 6 de maio de 1994, assim como a Nota de orientação apresentada pelo Diretor Geral da UNESCO, com vistas à preparação da Conferência Internacional para o Desenvolvimento Social, UNESCO, 29 de julho, de 1994.

7 Em análise da economia global publicada na edição de $1^{\circ}$ de outubro de 1994, The Economist juntou as economias do Terceiro Mundo, dos países do Leste Europeu e da ex-União Soviética sob o termo "países em vias de desenvolvimento" em oposição aos "países industrializados".

8 Cf. Laura Balbo (1994), From Welfare State to caring society contribuição preparada para o Colóquio internacional Políticas públicas, ações populares e desenvolvimento social organizado por UNESCO, Universidade e cidade de Bolonha, Bolonha 2 e 3 de dezembro de 1994.

9 A ociosidade forçada situa-se ao oposto da revolução do tempo liberado pelos avanços da produtividade, à medida em que esta implica uma redução do tempo de trabalho heterônomo daqueles que já foram socializados pelo trabalho. Ivan Illich (1977) e André Gorz (1988) mostraram muito bem como o tempo liberado podia se traduzir em atividades autônomas, econômicas e não-econômicas, contribuindo assim ao enriquecimento cultural e à plenitude da vida. Entretanto, o título propositalmente provocador do livro de Illich - O desemprego criador - pode confundir. Para a discussão da revolução do tempo liberado, ver também Echanges ê projets (1980), Sachs (1984) e Aznar (1993).

10 Entrevista dada ao jornal Le Monde, em 16 de novembro de 1993.

11 Não há por que esperar uma forte criação de empregos pela substituição do assalariado por formas de participação nos lucros das empresas (sharing economy) postuladas por J.Meade (1986) ou M.L. Weitzman (1985). Ver a esse respeito Brunetta (1994).

12 Como diz prudentemente Anizur Rahman Khan (1993:67), é muito difícil comprovar de modo convincente que os programas de ajuste tenham logrado proteger os interesses dos pobres!

13 Para mais detalhes, ver Sachs (1994).

14 Ler também Ricardo Petrella (1994). Ao opor-se diretamente à tese de Reich (1992), Paul Krugmann (1994) foi, entre os economistas americanos, aquele que via com maior clareza o perigo de atribuir importância excessiva à competição pelos mercados externos, em prejuízo da questão fundamental do desenvolvimento do mercado interno. 
15 Dollfus (1994:9) escreve: "Uma nova forma de exclusão nasce com a economia e o mercado mundiais: a exclusão dos inúteis, daqueles que não podem ou não querem vender as próprias aptidões e força de trabalho, não têm suficiente capacidade de compra para interessar o mercado por causa de sua pobreza. Inúteis localizam-se em regiões inteiras do mundo tanto quanto dentro das próprias sociedades consideradas prósperas".

16 Para uma análise das características mais significativas das políticas baseadas nos princípios do consenso de Washington, no contexto indiano, ver: Nayyar (1993), Taylor (1994) e também, Comeliau (1994).

17 Essas tipologias devem servir de referencial para pesquisar os casos históricos concretos e não ser concebidas como umas tantas gavetas, que servem apenas para classificar tal ou qual país.

18 O historiador e o agente de desenvolvimento têm muita coisa em comum. A única diferença é que o historiador interpreta o passado já realizado, ao passo que o agente de desenvolvimento tem a ambição de infletir a história do futuro. A interdisciplinaridade e o comparatismo tais como os praticam os historiadores encerram preciosos ensinamentos para os agentes de desenvolvimento.

19 A palavra inglesa resourcefulness (engenhosidade para transformar em recursos) é um conceito-chave para o ecodesenvolvimento.

20 O economista polonês Hausner (1994) fala em estratégia negociada entre os atores sociais. A experiência da planificação francesa vai no mesmo sentido.

21 Eis uma pergunta tipicamente gandhiana que, porém, aplica-se, em primeiro lugar, às sociedades industrializadas e se encontram numa forma um tanto diferente em certos representantes do pensamento católico; ver particularmente as encíclicas de João Paulo II (1994). A mesma pergunta suscitou um debate veemente na Suécia (ver Que faire? (1975).

22 Para uma seleção de suas obras, ver Economie \& humanisme (1986).

23 Para mais detalhes, ver Sachs, (1993).

24 O livro de Henri Bartoli (1991) sobre a economia multidimensional abre-se pela seguinte citação de Pascal: "O homem necessita de lugar para contê-lo, de tempo para durar, de movimento para viver, de elementos para compô-lo, de calor e alimento para alimentar-se, de ar para respirar; ele vê a luz, sente os corpos; tudo se sujeita à sua aliança... Sendo, portanto, todas as coisas causadas e causantes, auxiliadas e auxiliantes, mediatas e imediatas, interligando-se todas elas por um vínculo natural e insensível que une as mais longínquas e diferentes, tenho por impossível conhecer as partes sem conhecer o todo e tampouco conhecer particularmente as partes".

25 Que pena que a língua francesa não possua o equivalente da palavra inglesa bumane e o PNUD tenha escolhido buman no lugar de humane.

26 Ver especialmente a esse respeito a obra pioneira de Goldemberg et al., (1988) e os trabalhos de Benjamin Dessus (1995), sintetizados em sua tese.

27 Para mais detalhes e particularmente para as prescrições de políticas a serem seguidas, 
ver a declaração de Carnoules reproduzida em Development alternatives newsletter. v.4, n.12, dez. 1994 (Nova Delhi).

28 Não se deve confundir o setor fora do mercado (atividades voltadas para a subsistência da família) com a economia informal, que constitui um aspecto da economia de mercado.

29 Ver a esse respeito os livros de Chalmer Johnson (1992), Christian Sautter (1987) e Roberto Wade (1990), assim como os artigos já citados de Deepak Nayyar e Lance Taylor e a exposição de Robert Delorme (1995) sobre a abordagem postulada pelos adeptos da economia evolucionista.

30 A busca de novas formas da educação para a cidadania, da aprendizagem dos papéis sociais desde a escola primária, vem juntar-se às muitas funções, digamos clássicas, da educação e formação nas estratégias de desenvolvimento. Ver o documento já mencionado do Diretor Geral da UNESCO preparado para a Conferência internacional de Copenhague (nota 6).

31 Isso nos remete ao debate sobre as necessidades fundamentais, cuja versão fraca é estabelecida pelas autoridades, enquanto os interessados escolhem sua versão forte quando são eles mesmos que as hierarquizam. Ver a esse respeito Wisner (1988) e a contribuição fundamental de Sen $(1986,1987,1992)$ para a teoria da satisfação das necessidades, a qual mostra a diversidade das formas que podem interferir (entitlements).

32 Uma das primeiras medidas tomadas pelo novo presidente do Brasil, Fernando Henrique Cardoso, foi a de instaurar um ambicioso programa intitulado Comunidade solidária, baseado no princípio da parceria entre o Estado e os movimentos de cidadania.

33 Ver a esse respeito o estudo de Laura Balbo apresentado em Bolonha (nota 8), o livro de Pierre Rosanvallon (1995) e, para os antecedentes desses debates, o estudo preparado pelo Secretariado dos Estudos sobre Futuro na Suécia (Lägergren, M. et al., 1984). O desenvolvimento do Terceiro Setor no mundo acabou de ser o tema de um conjunto de relatórios organizados por Civicus, a Aliança Mundial para a Participação dos Cidadãos: ver, para a América Latina, Rubem César Fernandes (1994) e, para o Leste Europeu, E. Les (1994).

34 É exatamente nessas questões que o programa da UNESCO sobre o Gerenciamento das transformações sociais (MOST) concentra suas atividades de pesquisa e propostas de novas políticas - Ver o texto em destaque sobre MOST.

35 Sobre as perspectivas e os perigos que representa o crescimento da biotecnologia para os países do Sul, ver especialmente Biotechnology revolution in the third world (1988), Ahmed (1992) e Sasson (1993).

36 Ver a esse respeito Moulik (1988) e Sachs \& Silk (1990).

37 Para uma análise dos fatores determinantes do sucesso italiano de industrialização moderna descentralizada, que trouxe riqueza para o Nordeste da Itália, ver particularmente Bagnasco (1988), Pyke; Beccatini \& Sengenberger (1990) e Pyke \& Sengenberger (1992). Trigilia (1992) examina as razões do malogro da transposição mimética do modelo para o Sul do país. 
38 Esse é o objetivo visado pelo programa de cooperação Sul-Sul para um desenvolvimento sócio-econômico que respeite o meio-ambiente nos trópicos úmidos. Ver Perspectives Sud-Sud n:1, out. 1994, carta informativa publicada pela UNESCO.

39 Ver particularmente a esse respeito Holland (1994).

40 A Comissão Internacional sobre a Educação para o século XXI, presidida por Jacques Delors, e a Comissão Mundial sobre Cultura e Desenvolvimento, estabelecida sob a presidência de Javier Perez de Cuellar.

MOST / Gerenciamento das transformações sociais: um novo programa da UNESCO.

MOST (Management of Social Transformations) foi criado pela UNESCO, em 1994, para favorecer a pesquisa comparativa internacional sobre transformações sociais e desenvolvimento. Seu objetivo é, a um só tempo, contribuir para o melhor conhecimento desses processos e destacar a pertinência das pesquisas em Ciências Sociais para decidir e elaborar políticas.

MOST concentra suas atividades no gerenciamento da mudança nas sociedades multiculturais e multiétnicas; nas cidades enquanto espaços de transformações sociais aceleradas; e no gerenciamento local das transformações econômicas, tecnológicas e ambientais. Dando continuidade à Conferência Social Internacional, haverá concentração em novo campo de atividades ligadas à luta contra a exclusão social e às políticas de coesão social.

O programa é monitorado por um Conselho intergovernamental composto por 33 Estados, assim como por um Comitê diretor científico, formado por nove pesquisadores internacionais, nomeados individualmente.

Referências bibliográficas

AHMED, I. (ed.). Biotechnology. A hope or a threat? A study prepared for the International Labour Office within the framework of the World Employment Programme. Londres, The MacMillan Press Ltd., 1992.

AZNAR, G. Travailler moins pour travailler tous. Paris, Syros, 1993.

BADIE, B. \& SMOUTS, M.C. Le retournement du monde. Dalloz, Paris, Presses de la Fondation Nationale des Sciences Politiques, 1992.

BADIE, B. Nouvel ordre du nouveau désordre mondial. Paris, Cercle Condorcet, Les Points de Vue n. 13, nov. 1994.

BAGNASCO, A. La construzione sociale del mercato. Bologne, Il Mulino, 1988.

BALBO, Laura (ed.). Time to care, politiche del tempo e diritti quotidiani. Milan, Franco Angeli, 1987.

BARTOLI, H. L'économie multidimensionnelle. Paris, Economica, 1991.

BELORGEY, J.M. Evaluation de la politique de la ville. Hommes, Libertés et Territoires, fev./mars 1994. 
BIOTECHNOLOGY REVOLUTION and The Third World. Challenges and policy options. New Delhi, Research and Information System for the Non-Aligned and Other Developing Countries (RIS), 1988.

BIT, Population active 1950-2025, Geneve, Mundo resumido, v.5, 1986.

BRUNETTA, R. La fine della società dei salariati, Venise, I. Grilli Marsilio, 1994.

BRUNHES, B. Entretien. In: Mazel, O., Les chômages, Paris, Le Monde éditions, 1993, p.169.

CALVINO, I. Les villes invisibles, Paris, Le Seuil, 1974.

CASTEL, R. Les métamorphoses de la question sociale - une chronique au salariat. Paris, Fayard, 1995.

COMELIAU, Ch. Ingérence économique. La mécanique de la soumission, Paris, Les Nouveaux Cahiers de L'Instit Universitaire d'Etudes du Développement de Genève, Presses Universitaires de France, 1994.

DELORME, R. An evolutionary theoretical framework for the state economy interactions in transforming economies, contribuição para a mesa redonda sobre as formas de organização e transformação nas economias da Europa Central e Oriental, Paris, 26-27, jan. 1995.

DESSUS, B. Systèmesénergétiques pour un développement durable, Grenoble, Tese (Doutorado). Grenoble, France, Universisté Pierre Mendès, 1995.

DOLLFUS, O. L'Espace Monde, Paris, Economica, 1994.

DRÜCKER, P.F. The changed world economy. In: Foreign Affairs, p. 768-791.

EHRLICH, Paul R. \& ANNE H. The population explosion, New York, Simon and Schuster, 1990.

EMMERIJ, L. Tensions sociales et réforme sociale en Amérique Latine, comunicação apresentada no Fórum Internacional sobre as Perspectivas Latino-Americanas, organizado pelo BID e o Centro de Desenvolvimento da OCDE, Paris, 2-4, nov. 1994.

ETZIONI, A. The spirit of community. Rights, responsabilities and the communitarian agenda. New York, Crown Publishers, 1993.

FRIEDMANN, J. Empowerment: the politics of alternative development. Blackwell, Cambridge, Mass \& Oxford, 1992.

GOLDEMBERG, J.; REDDY, A.K.; WILLIAMS, R. \& JOHANSSON, Th. Energy for a sustainable world. New Delhi, Wiley Eastern Limited, 1988.

GORZ, A. Métamorphoses du travail: quête du sens. Paris, Galilée, 1988.

GOWARIKER, V. (ed.). The inevitable billion plus. Science, population and development. Pune, Unmesh Communications, 1992.

HAUSNER, J. Negotaited in the transformation of post-socialist economy. Cracovie, Cracow Academy of Economies, 1994. 
HOLLAND, S. Towards a new Bretton Woods. Alternatives for the global economy. Nottingham, Spokesman, 1994.

ILLICH, I. Le chômage créateur. Postface à la convivialité. Paris, Le Seuil, 1977.

JEAN-PAUL II. Questions sociales. Travail-developpement-economie. Paris, Librairie Générale Française, 1994.

JOHNSON, CHALMERS. MITI and the Japanese miracle. Stanford, Stanford University Press, 1982.

KEYNES, J.M. Perspectives économiques pour nos petits-enfants. In: Essais sur la monnaie et l'économie. Paris, Payot, 1971.

KOTHARI, R. Growing amnesia An essay and the human consciousness. New Delhi, Viking/Penguin Books, 1993.

KRUGMAN, P. Peddling prosperity. New York, W.W. Norton, 1994.

KULA, W. Secteurs et régions arriérés dans l'économie du capitalisme naissant. Studi Storici, n.3, 1959/60.

LEADBEATER, Ch. \& LLOYD, J. In search of work. Harmondsworth, Penguin Books, 1987.

LEBRET, Louis-Joseph (ed.). Economie et humanisme. Lyon, Regards, 1986.

LES, E. The voluntary sector in post-communist east central Europe. From small circles of freedom to civil society. Washington, Civicus, 1994.

MADDISON, A. Monitoring the world economy 1820-1992. OCDE Centre de développement, 1994.

MEADE, J. Agathotopia. L'economia della partnership. Milano, Feltrinelli, 1989.

- Different forms of share economy. London, Public Policy Center, 1986.

MICHEL. Albin (ed.). La révolution du temps choisi, Paris, Echange et Projets, 1980.

MORIN, E. \& KERN, A.B. Terre-patrie. Paris, Editions du Seuil, 1993.

MOULIK, T.K. (ed.). Food-energy Nexus and Ecosystem. New Delhi International Symposium on Food- Energy Nexus and Ecosystem. 2. New Delhy, Índia, 12-14 Feb. 1986. Proceedings. New Dehli, Mohan Primlani for Osford \& IBH Publishing, 1988.

NAISBITT, J. Global paradox. New York, Avon Books, 1995.

NAYYAR, D. The Indian economy at crossroads: illusions and realities. Bangalore, Frontier Lecture of the Jawaharlal Nehru Centre for Advances Scientific Research and the Indian Institute of Science, 25 Fév. 1993.

ORTIZ, R. Mundialização e cultura. São Paulo, Brasiliense, 1994.

PETRELLA, R. Litanies de sainte compétitivité. Le Monde Diplomatique, Maniére de Voir 22, mai, 1994. 
PNUD. Rapport mondial sur le développement humain. Programa das Nações Unidas para o Desenvolvimento, 1994.

PYKE, F. \& SENGENBERGER, W. (eds.). Industrial districts and local economic regeneration. Genève, International Institute for Labour Studies, 1992.

PYKE, F.; BECATTINI, G. \& SENGENBERGER, W. (eds.). Industrial districts and inter-firm co-operation in Italy. Geneve, Internactional Institute for Labour studies, 1990.

QUE FAIRE? Relatório Dag Hammarskjöld sobre o desenvolvimento e a cooperação internacional Uppsala. Development Dialogue, n.( 1/2, 1975.

RAHMAN KHAN, A. Structural adjustment and income distribution. Genève, Issues and Experiences, ILO, 1993.

RAMONET, I. Un horizon d'espoir. Le Monde Diplomatique. Paris, Manière de voir n. 22 , mai 1994.

REICH, R. The work of Nations. Preparing ourselves for 21th century capitalism. New York, Vintage Books, 1992.

RIBOUD, A. Modernisation, mode d'emploi. Paris, Union générale d'édition, 1987.

RIGAUDIAT, J. Réduire le temps de travail. Paris, Syros, 1993.

RISANVALLON, P. La nouvelle question sociale. Paris, Repenser l'Etat-providence, Le Seuil, 1995.

RUFFOLO, G. Potenza e potere. La fluttuazione gigante dell'Occidente. Bari, Laterza, 1988.

SACHS, I. Développer les champs de planification. Paris, Université Coopérative Internationale, p. 128 (série Cahiers de L'UCI, n. 2, 1984.

SACHS, I. L'écodéveloppement, stratégies de transition vers le XxIéme siècle. Paris, Syros, 1993.

SACHS, I. Les temps-espaces du développement. Paris, Diogène, n. 112, p.80-95, 1980.

SACHS, I. Population, developpement et emploi. Toulouse, Revue Internationale des Sciences Sociales, n. 141, p. 409-426, UNESCO/Erès, 1994.

SACHS. I. \& SILK, D. Food and energy: strategies for sustainable development, Tóquio, United Nations University Press, p.83, 1990.

SAINT-GEOURS, J. Moi et nous. Politique de la societé mixte. Paris, Dunod, 1992.

SALOMON, J.J. Prométhée empêtré. - La résistance au changement technique. Paris. Ver também, do mesmo autor Le destin technologique, 1992, Balland, Paris e (dir. pub.) J.J. Salomon, F. Sagasti \& C. Sachs-Jeantet, La quête incertaine. Science, technologie, développement, Economica, 1984.

SASSON, A. Biotechnologies in developing countries: present and future. Paris, UNESCO, v.1, 1993, p.164. 
SAUTTER, Ch. Les dents du dragon. Paris, Orban, 1987.

SEN, A. Food, economics and entitlements. Helsinki, Wider Working Paper 1, 1986.

_. Inequality reexamined. Cambridge, Mass, Harvard University Press, 1992.

_. On ethics and economics. Oxford, Blackwell, 1987.

SENGENBERGER, W.; LOVEMAN, G.W. \& PIORE, M.J. The re-emergence of small enterprises: industrial restructuring in Industrialised countries. Genève, International Institute for Labour Studies, 1990.

SERRES. P. Le contrat naturel. Paris, François Bourin, 1990.

STREETEN, P. Mobilizing human potential. The challenge of unemployment. New York, UNDP Policy Discussion Paper, UNDP, 1989.

SWAMINATHAN, M.S. (ch). Uncommon opportunities. An agenda for peace and equitable development. International Commission on peace and food. London et New Jersey, Zed Books, 1994.

TAYLOR, L. Economic reform: India and elsewhere. New Delhi, Economic and Political Weekly, 20 Aug. 1994.

THE GROUP OF LISBON, Limits to competition. Lisbonne, Gulbenkian Foundation, 1993.

TRIGILIA, C. Sviluppo senza autonomia. Effetti perversi delle politiche nal mezzogiorno Bologne, Il Mulino, 1992.

TSURU, S. Japan's capitalism: creative defeat and beyond. Cambridge, Cambridge University Press, 1993.

WADE, ROBERT. Governing the market: economic theory and the role of government in East Asian industrialization. Princeton, Princeton University Press, 1990.

WEITZMAN, M.L. L'economia della participazione. Bari, Laterza, 1985.

WISNER, B. Power and need in Africa, Londres, Earthscan Publications Limited, 1988.

WOLFE, M. Some pardoxes of social exclusion Genève, International Institute for Labour studies, Discussion paper 63/1994, 1994.

Resumo

Na véspera da Conferência sobre desenvolvimento social em Copenhague (1995), o autor defende novas estratégias condizentes com uma axiologia do desenvolvimento. Para ele, não há desenvolvimento sem crescimento equilibrado dentro de cada país e nas relações Norte-Sul. Por outro lado, não se pode prescindir da ecologia. Finalmente o objetivo do desenvolvimento é o homem, sua cultura própria, seus valores universais: o direito à inserção produtiva e à participação enquanto cidadão, o que supõe um Estado democrático, regulador de uma economia mista. No plano jurídico, o autor sugere a criação de um foro internacional independente. 


\begin{abstract}
On the eve of the International Social Conference in Copenhagen (1995), the author defends new strategies, suitable for a development axiology. According to him, there is no development without a balanced growth within each country and in the NorthSouth relations. On the other hand, one cannot ignore ecology. Finally, the target of development is man, his own culture, his universal values: the right to a productive insertion and to the participation as a citizen. This pressuposes a democratic State, regulator of a mixed economy. At the juridic level, the author suggests the creation of an independent international forum.
\end{abstract}

Ignacy Sachs é professor da Escola de Altos Estudos em Ciências Sociais de Paris e diretor do Programa da Universidade das Nações Unidas. É autor de extensa obra, com quatro livros publicados no Brasil: Capitalismo de Estado e subdesenvolvimento (Vozes, 1969), Ecodesenvolvimento - crescer sem destruir (Vértice, 1981), Espaços, tempos e estratégia do desenvolvimento (Vértice, 1986) e Estratégias de transição para o século XXI (Nobel-Fundap, 1993, ).

Tradução de Jean Briant. O original em francês - A la recherche de nouvelles estratégies de développment - encontra-se à disposição do leitor no IEA-USP para eventual consulta.

Texto elaborado pelo autor em fevereiro de 1995 a pedido da UNESCO. 